\title{
A Comparative Study on the Examination System of CPA in the Al Evelopment Background Take China, Australia, the United States, the United Kingdom, Japan, and Germany as examples
}

\author{
Chao Zhang ${ }^{1 s t, a}$, Xinglin Li ${ }^{\text {2nd,b*, Yuzhu Qi }}{ }^{\text {3rd,c }}$, Yitong He ${ }^{\text {4th,d }}$, Jingwei Niu ${ }^{\text {th,e }}$, Yiyi Xu ${ }^{\text {th,f, }}$, Jiaying Zhang ${ }^{\text {th, }, \mathrm{g}}$ \\ ${ }^{1}$ Jilin University of Finance and Economics JUFE Changchun, China \\ ${ }^{2}$ Jilin University of Finance and Economics JUFE Changchun, China \\ ${ }^{3}$ Jilin University of Finance and Economics JUFE Changchun, China \\ ${ }^{4} \mathrm{Jilin}$ University of Finance and Economics JUFE Changchun, China \\ ${ }^{5}$ Jilin University of Finance and Economics JUFE Changchun, China \\ ${ }^{6} \mathrm{Jilin}$ University of Finance and Economics JUFE Changchun, China \\ ${ }^{7}$ Jilin University of Finance and Economics JUFE Changchun, China
}

\begin{abstract}
At present, the globalization of the world economy continues to intensify, and the pace of technological modernization is accelerating. Artificial intelligence methods such as big data and financial sharing are gradually replacing traditional working methods in all walks of life, and the accounting industry is no exception. Under the dual impact of globalization and the development of artificial intelligence, the demand for training international compound accounting professionals is large and increasing, "CPA examination system" as one of the most authoritative examinations in the field of accounting, its matching with the current environment is particularly important. Starting from the current status of CPA examination, the author has made an in-depth investigation and study on the CPA examination systems in many countries including China, the United States, Britain, Japan, Germany and Australia by consulting a large number of relevant literature. Meanwhile, they systematically analyzed the CPA examination systems in various countries from four dimensions: examination organization, examination threshold, examination cycle and examination subjects, explored the similarities and differences of CPA examination systems in the world's mainstream countries, and summarized the common problems and the advantages that can be used for reference, which has practical significance for the design and update of the CPA examination system in China. At the same time, it provides reference significance for improving the professional quality of accounting personnel and accelerating the pace of changing the functions of accounting personnel.
\end{abstract}

\section{Introduction}

On the Background of the further strengthening of economic globalization, the increasing convergence of accounting standards, and the gradual opening of the accounting market, how can we cultivate high-quality and high-level CPA professionals in an increasingly competitive environment, so that CPAs can adapt to the times, and maintain the healthy and sustainable development of the CPA industry is the starting point and goal of the current development of the CPA industry. As the industry's vane, the CPA examination is bound to face the process of continuous improvement and development. Since China began to implement the CPA examination in 1991, it has a history of 29 years, and it has become one of the national vocational qualification examinations generally accepted by the society and recognized by the industry. The CPA examination has carried out three large-scale system reforms successively: In 2009, the
Chinese Institute of Certified Public Accountant (be called "CPA" for short) promulgated the "CPA Examination System Reform Plan", which divided the examination into a professional stage and a comprehensive stage. The " $6+1$ " examination mode regulates that candidates can only participate in the comprehensive examination in the following year after passing the six professional examinations. This measure has laid a solid foundation for China's current CPA examination system; in 2012, in order to comply with the development of the times, the CPA examination began to adopt a no-paper computer-based examination mode, which improved the safety and scientific of the examination, further improved the relevant examination organization system, and finally completed the task of reforming the examination organization system successfully; in 2015, on the basis of summarizing the first two reform experiences, the CICPA issued the "CPA Examination Quality Assurance System Reform Plan". Through reference to relevant examination institutions such as other countries and international organizations, it

\footnotetext{
"Corresponding author: ${ }^{\mathrm{a}} 1522858958 @ q \mathrm{qq.com}$

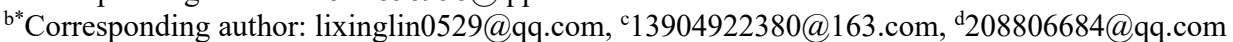

f1272790418@qq.com, e2034305551@qq.com, ${ }^{\mathrm{g}} 1872084570 @ q \mathrm{qq.com}$
} 
vigorously promotes the construction of the CPA examination question bank and continuously improves the CPA examination. The system improves the quality of the CPA professional training program system, enhances the comprehensive level of economic management and accounting, and further integrates the Chinese CPA examination with the international CPA examination. In summary, the reform of the CPA examination system is inextricably linked to social development and economic levels. Changes in the general environment such as society and economy have a significant impact on the development of the CPA industry. [1]

At present, on the one hand, the development of the CPA examination system in China should conform to the development of socialism with Chinese characteristics in the new era, and on the other hand, it should appropriately learn from the examination modes of other countries and regions, especially the relatively mature examinations in developed countries such as Britain, the United States, and Japan. The mode strives to achieve the goal of integrating the Chinese CPA examination system with the internationally recognized examination system, thereby promoting the continuous development and improvement of the Chinese CPA examination system. This article will sort out and analyze the CPA examination systems of various countries from the four aspects of examination organizer, examination threshold, examination period, and examination subjects, in order to discover the similarities and differences, and be able to take the essence and eliminate the dross, for the future Chinese CPA examination System improvement and industry development provide a reference.

\section{RESEARCH SAMPLE SELECTION}

This article selects countries that are representative of the CPA examination system in the world for comparative research. Since most countries do not have a relatively complete CPA examination system or are based on the examination modes of developed capitalist countries such as the United States and the United Kingdom, this article finally selects six countries including China, the United States, the United Kingdom, Japan, Germany, and Australia as research objects.

This article mainly obtains information from relevant domestic, foreign literature and relevant websites of CPA associations in various countries and summarizes. It mainly researches examination organizers, examination thresholds, examination periods, and examination subjects. The specific analysis is as follows.

\section{RESEARCH ON EXAM ORGANIZERS}

According to the official website of certified public accountants in various countries and related literature records, the CPA examination organizers in the research sample are mainly divided into two types: the national statutory qualification examination and the self-organized examination of the association. Among them: the national statutory qualification examinations include China, the United States, Japan, Germany, Australia, the only one that is self-organized by the association is the United Kingdom. Next, the author will explain the organizers of each research sample examination.

\subsection{China}

The Chinese Certified Public Accountant Examination (CICPA) is implemented in accordance with the "Law of the People's Republic of China on Certified Public Accountants" and is a unified national examination for the selection of statutory professional qualifications for accounting professional and technical personnel. It started in 1991 and was launched by the Institute of Certified Public Accountants in accordance with the Measures for the Unified National Examination of Certified Public Accountants. Founded in November 1998, the Chinese Institute of Certified Public Accountants is a statutory organization under the Ministry of Finance that is engaged in the management and service of corresponding industries. In all provinces, autonomous regions, and municipalities directly under the Central Government, the Institute of Certified Public Accountants has established local examination offices to organize and implement centralized areas to conduct unified national examinations for certified public accountants. As of the end of June 2019, the Chinese Institute of Certified Public Accountants had a total of 9,118 member units (accounting firms), of which 40 accounting firms obtained securities and futures qualifications, and 11 accounting firms obtained $\mathrm{H}$-share corporate audit qualifications. The AICPA has more than 260,000 individual members, including 107,483 practicing members and 153,891 nonprofessional members. The AICPA currently has 2,818 senior members and 17 honorary members. Currently, China has nearly 400,000 employees in the industry, of which 260,000 have the qualifications of certified public accountants. They mainly serve more than 4.2 million enterprises and administrative institutions including more than 3,000 listed companies.

\subsection{United States}

The American Certified Public Accountant Examination (USCPA) is a professional certification under the American Institute of Certified Public Accountants (AICPA). It is also the only official national uniform statutory qualification examination for certified public accountants in the United States. AICPA was established in 1886 with only 31 members at the time of its establishment. As of 2019, it has nearly 650,000 members in 128 countries and regions. It has reached mutual qualification agreements with professional accountants in 8 different countries and regions (but it has not formed a mutual exemption system with the Chinese CPA Examination) and is currently the world's largest accountant association. But compared with other exams, the USCPA can only take the exam in the United States and its territories. At present, most Asian candidates choose to go to Guam, Japan for the exam. [2] 


\subsection{United Kingdom}

The British Chartered Accountant Examination (ACCA) is organized by the Institute of Chartered Accountants in England and Wales (ICAEW). ICAEW is currently one of the most authoritative accounting professional organizations in the world. It was established in 1880 and is under the supervision of the British Financial Reporting Council (CFK) supervision. It is headquartered in London, England. It has a total of 154,000 members distributed in 149 countries around the world. It has reached agreements on mutual recognition of qualifications with professional accountant organizations in 14 different countries and regions and formed a mutual exemption system with the Chinese CPA examination. Currently, ICAEW has worked closely with more than 5,000 employer companies.

\subsection{Japan}

The Japanese Certified Public Accountant Examination (JICPA) is a national statutory qualification examination uniformly implemented by the Japan Certified Public Accountants Association in accordance with the Japanese Certified Public Accountant Act. The Japan Certified Public Accountants Association is a professional organization composed of certified public accountants and is a public interest legal person which is committed to improving the overall practice level of the industry and maintaining the integrity of the industry so that the company will continue to develop healthily. Founded in 1949, it is headquartered in Tokyo and has branches in various places. As of March 31, 2016, Japan had 35,510 certified accountants, including 28,289 certified accountants and 214 supervisory legal persons.

\subsection{Germany}

The German Statutory Auditor Examination (WP for short) is a national statutory qualification examination implemented by the German Association of Statutory Auditors (WPK) under the supervision of the German Federal Ministry of Economics and Labor Affairs in accordance with the German Statutory Auditor Act. WPK is a public law association formed by practitioners in the statutory auditing industry established in accordance with the law and carries out corresponding work under government supervision. It is mainly responsible for the professional qualification management and professional quality supervision of statutory auditors. As of the end of 2019, WPK had a total of 21,097 members, including 14,568 auditors, 2,377 certified auditors, 2,982 auditing companies, 73 accounting firms, and 1,097 other members. [3]

\subsection{Australia}

The Australian Certified Public Accountant (AUCPA) is a national statutory qualification examination organized by the Australian Institute of Certified Public Accountants in accordance with relevant Australian laws. Its goal is to cultivate talents in the fields of accounting and business and help members comprehensively improve their professionalism from multiple dimensions such as strategy, operation and management, cultivate innovative thinking and open up communication. As one of the largest professional accounting organizations in the world, CPA Australia was founded in 1886 and is headquartered in Melbourne. It has five offices in Hong Kong, Macau, Beijing, Shanghai and Guangzhou in China. As of the end of 2018, it has a total of There are 164,695 members from more than 150 countries and regions.

\subsection{Summary}

In summary, it can be found that in most countries, the CPA examinations are supported by relevant laws, and the executive agencies are organized under the national functional departments, which are national statutory qualification examinations. Under normal circumstances, candidates will verify the exam organizer when they choose to prepare for an exam. If the organizer is more authoritative, such as an association affiliated with a national functional department or a prestigious association in the industry, the candidate will choose the exam whose intention is higher. If the situation is the opposite, the examinee's intention to choose this type of examination is lower.

\section{RESEARCH ON EXAMINATION THRESHOLD}

Since the CPA industry is a professional service industry, not all citizens can enter the industry, so countries will set their entry thresholds based on their own specific conditions, so that they can select talents in the industry more efficiently and accurately. At present, in the six research samples, the setting of examination thresholds is mainly divided into two categories: whether academic qualifications are required and whether they have practical experience requirements. Next, this article will explain the examination thresholds of each research sample.

In the research sample, five countries including China, the United States, the United Kingdom, Germany, and Australia have clear requirements for academic qualifications or practical experience. Japan has no clear restrictions on the CPA examination threshold, as follows: China has high requirements for candidates applying for CPA examinations A college degree or above, or an accounting or related professional intermediate or higher technical title; different states in the United States have different registration requirements for the exam. Most regions require a bachelor degree, and more than 150 accounting or business credits are required (a few regions require 120 credits), if it is a college degree or above recognized by the Chinese state, it is usually recognized and does not limit the professional threshold; the UK requires a high school degree or higher for candidates applying for CPA, and must sign and complete with an institution or firm recognized by ICAEW A training agreement; Germany has stricter requirements for 
candidates for the CPA examination, requiring a university degree or above. If the academic qualifications are not met, they must meet the requirements of having more than 10 years of audit experience; Australia's CPA examination threshold is relatively low, the application conditions and requirements are more flexible. Any candidate who is interested in the Australian CPA course can directly apply for Ethics and Governance without submitting an assessment application. The test results are valid for 6 years. [4]

\section{RESEARCH ON EXAM CYCLE}

The professional examination subjects and comprehensive examination subjects of the Chinese Registered Accounting Examination are held once a year respectively. The six course scores of the professional examination subjects are valid for five years. The single-stage mode of the American Registered Accounting Examination adopts a once-a-year examination cycle, and the effective time of each subject score is set for 18 months. You can pass these 4 courses in 10 exams at most. That is to say, after passing a subject, candidates need to complete and pass the remaining exams within the validity period of 18 months, and cannot exceed the limit of 10 times. If the time limit is exceeded, the scores of the previously passed exam subjects are also invalid. There are 13 exams in the UK ACCA exam. Students need to complete the exam within 10 years after registration. Compared with other countries, there are a few more exams and the exam period is relatively longer. Japan adopts the "112" mode according to the assessment content of different stages, that is, the first and second stages are held once a year, and the third stage is held twice a year. Germany has strict requirements for the examination cycle. It stipulates that each examinee has only three opportunities to take the examination. The selection of talents is highly targeted, and the qualifications for the selection and certification of certified public accountants are also very demanding, which imposes professional knowledge and psychological quality on examinees. And the comprehensive ability is required. Australia has set a maximum of 3 exams each semester, and the exam process is gradual, and after passing the exam, you must have worked in the industry for 3 years before you can obtain the Australian CPA qualification.

\section{RESEARCH ON EXAMINATION SUBJECTS}

According to the official website of CPA examinations and reference materials in various countries, the examination forms of CPAs in the research countries are divided into three types: single-stage, double-stage and multi-stage. Among them, the United States adopts a single-stage assessment mode, China, the United Kingdom, and Germany adopt a two-stage assessment mode, and the rest of the research objects adopt a multistage assessment mode. Different examination subjects are placed in different stages by different countries, and the registered accounting examination systems reflected in them also have their own characteristics. The following author will follow the content, form, and question types of the registered accounting examination subjects in different countries Make relevant explanations.

\subsection{China}

The two-stage examination in China is divided into two aspects: professional examination subjects and comprehensive examination subjects. The professional examination subjects as part of professional theoretical knowledge are divided into "Accounting", "Audit", "Financial Cost Management", "Economic Law", "Tax Law", and "Company". Since the restoration and reconstruction in 1994, the subject of "Corporate Strategy and Risk Management" has been added in accordance with the changes in the macro environment and the economic and market situation. The knowledge of the subject textbooks has also been revised and updated year by year, and the content of the courses has also been updated accordingly. modify. The question types are divided into single choice, multiple choice, short answer, calculation, case analysis, etc. The single subject is 100 points out of 100 , and 60 points or more is passed. As a comprehensive examination of professional ability, it is important to test whether candidates can comprehensively use accounting professional knowledge, whether they can adhere to professional values, abide by professional ethics, and adhere to professional attitudes.

The two-stage assessment system of the Chinese Registered Accounting Examination System is both professional and comprehensive, covering a wide range of knowledge, and combining actual cases for comprehensive and detailed investigation, which is in line with the national conditions of education with Chinese characteristics. However, each subject of the CPA examination in China is relatively independent, the knowledge system has a tendency to become fixed, and the professional examinations are based on evidence. There are many students who take exams for examinations and lack the practical professionalism of the accounting profession.

\subsection{United States}

The American CPA exam puts all subject assessments into one stage, which is a typical single-stage assessment mode. It selects four subjects: "Tax Law", "Auditing", "Business Environment", and "Financial Reporting" to examine the students. The question types also contain individual choices. However, unlike the Chinese CPA Examination, the remaining question types only have cases. The full score of each subject is 99 points, and a score of 75 or more is a passing test. Although there are only 4 subjects, the correct rate must be more than $75 \%$ in order to pass the exam. The case question types require more professional analysis in combination with the actual business, and certain experience in practice is also required.

In terms of test preparation content, USCPA ceases to publish complete textbooks for each test, and candidates 
are also not allowed to keep reference materials and test papers. These materials and test papers are printed with codes in advance, and they will be destroyed uniformly soon after the test. Before the exam, only the exam content outline and sample question types are issued for candidates to prepare for the exam. [5] This enhances the flexibility of the content of the examination, and focuses more on the examination of the overall quality of the candidates. Compared with China's more routine examination-oriented education, it can select accounting professionals with higher accounting professional ability.

\subsection{United Kingdom}

ACCA exam is also a two-stage assessment system, which is divided into a basic stage and a professional stage. The basic stage consists of knowledge modules and skill modules. The knowledge modules include three subjects: "Accountants and Enterprises", "Management Accounting" and "Financial Accounting". Skills modules include "Company and Commercial Law", "Performance Management", "Taxation", "Financial Reporting", "Auditing and Certification Business" and "Financial Management". The professional stage is divided into professional core modules and professional elective modules around the profession. It includes "SBL Strategic Business Leader" and "SBR Strategic Business Report" into the professional core modules of the ACCA exam. Candidates need to start from the "Advanced Finance" in the professional elective module. Choose two of the four subjects of Management, Advanced Performance Management, Advanced Taxation, and Advanced Auditing and Certification Services for examination. The British Chartered Accountant Examination has a total of 13 exam subjects. Candidates should take the exam in the order of stages and modules. The order of the exams for the same module can be freely chosen.

As shown in Figure 1, the British Association does not rely on the school's regular accounting courses. It organizes its own specialized education. Compared with the unified examination settings in China and the United States, 13 examination subjects are set up from the shallower to the deeper, and the association's students are specially trained. The assessment method is conducive to the precise control of the ability and expertise of accounting professionals, and is of great help to the construction of the system's accounting talent pool. However, there are many subjects and a wide range of professional and related knowledge, which may have a certain impact on the pass rate of the exam.

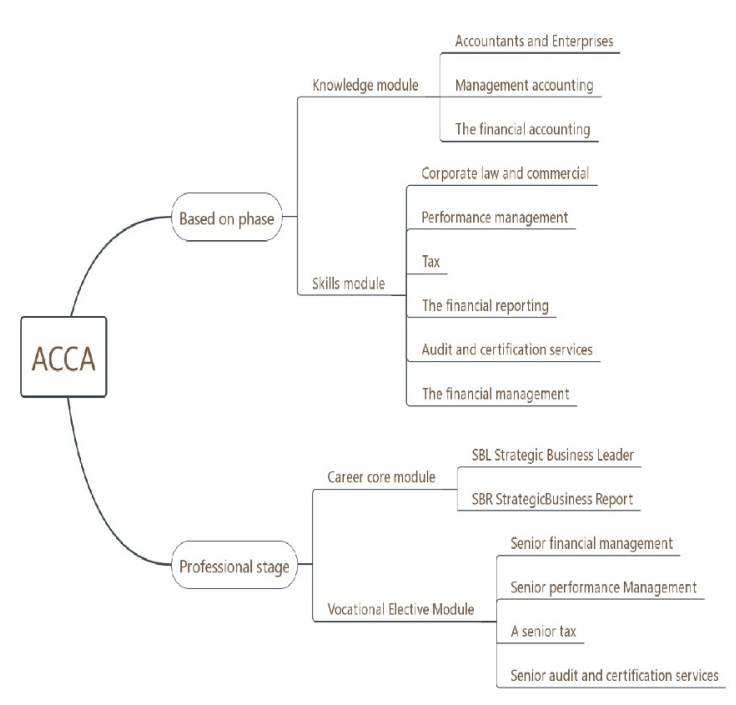

Figure 1. ACCA exam subject details

\subsection{Japan}

As the first country in Asia to establish a certified public accountant system, Japan's certified public accountant examination system is set up as a multi-stage assessment, including three stages: basic examination, professional examination, and application examination. Among them, the basic examination subjects include four subjects: Mandarin, mathematics, foreign language (English) and thesis (this part pays more attention to the basics, and it is stipulated that those with a college degree or above can be exempted); the professional examination begins to enter the inspection of accounting professional knowledge to determine whether the candidates have The professional knowledge required to serve as a certified public accountant requires different answering methods for different subjects. Among them, "Accounting" and "Business Law" are short-answer subjects, and the essay format takes the form of "1+2" for the examination. Among them, "Accounting" is a compulsory subject, and "Management", "Economics" and "Civil Law" Choose two of the three subjects to take the exam. The short answer is more basic than the essay, and only those who pass the short answer exam are eligible to take the essay exam.

The three stages of the Japanese Registered Accounting Examination gradually improve the inspecting level of accounting which is from basic to high-level accounting professional application capabilities.

Compared with the two horizontal aspects in China, they are more in-depth and will help cultivate more solid accounting Professionals, but lack of training and inspection of comprehensive practical ability, and also need to reform the system according to the current internationalization of the accounting profession and the national conditions. [6] 


\subsection{Germany}

Although Germany is also a two-stage assessment mode like China, its review format is quite different from other countries. The German registered accounting examination is divided into two parts: written examination and interview. The written examination includes "Tax Law One", "Tax Law Two", "Enterprise Valuation", "Professional Rules One", "Professional Rules Two", "Business Management and Economics One" and "Enterprise The content of "Management and Economics II" and "Company Law" covers a wide range of subjects. Candidates who have completed the above written examinations can enter the interview session. The professional subjects of the interview are the same as the content of the written test, only one "Career Law" related content is added. Through a comprehensive evaluation of the written test and interview results to determine whether the final score verdict is passed.

Compared with the countries studied before, Germany is more ingenious. It combines the needs of the current accounting market for practical talents. At the same time, it also focuses on international accounting expertise. It not only relies on academic education but also attaches importance to the independent training of the office. It is more targeted.

\subsection{Australia}

The Australian CPA Examination is also a multi-stage examination, divided into basic courses, professional courses, and practical stages. The full score of subjects in the three stages is 900 points, and the pass line is 540 points. Among them, the 6 basic courses are "Economy and Metrology", "Basic Accounting", "Basics of Commercial Law", "Business Finance", "Financial Accounting and Reporting" and "Management Accounting". The 6 professional courses consist of 4 compulsory courses and 2 elective courses; required courses include "Ethics and Governance", "Financial Reporting", "Strategic Management Accounting", "Global Strategy and Leadership"; elective courses include "Advanced Tax Law" and "Advanced Audit and Assurance, "Financial Risk Management", "Contemporary Business Issues", "Basics of Financial Planning", etc.

In the exam phase, you can apply for a maximum of 3 exams per semester. You must pass the basic exam or complete the corresponding course credits in the guildcertified school before you can enter the practical phase of learning. This guarantees the professional foundation of accounting. The practice stage is different from other countries, and the requirements are more detailed and specific. First, the trainees must work in related fields such as finance, accounting, and financial management; secondly, they must have a career guidance consultant during their work. More emphasis on practical experience in the field of accounting professional work.

TABLE I. LIST OF COMParative ANALysis OF COUNTRIES [7]

\begin{tabular}{|c|c|c|c|c|c|}
\hline $\begin{array}{c}\text { Test } \\
\text { abbreviation }\end{array}$ & $\begin{array}{c}\text { Number of test } \\
\text { stages }\end{array}$ & $\begin{array}{c}\text { Total number } \\
\text { of test subjects }\end{array}$ & $\begin{array}{c}\text { Exam passing } \\
\text { score }\end{array}$ & Advantages & Disadvantages \\
\hline CICPA & 2 & 6 & $60 / 100$ & $\begin{array}{c}\text { Professional and } \\
\text { comprehensive,Study } \\
\text { meticulously. }\end{array}$ & $\begin{array}{c}\text { Single for many } \\
\text { years, } \\
\text { The mode is more } \\
\text { solidified. }\end{array}$ \\
\hline USCPA & 1 & 4 & $75 / 99$ & $\begin{array}{c}\text { Fewer subjects, The } \\
\text { scope of investigation is } \\
\text { limited. }\end{array}$ & $\begin{array}{c}\text { The question type } \\
\text { and content } \\
\text { innovation cycle are } \\
\text { short and flexible. }\end{array}$ \\
\hline ACCA & 2 & 13 & $50 / 100$ & $\begin{array}{c}\text { The inspection is wide } \\
\text { and the selection is } \\
\text { highly targeted. }\end{array}$ & $\begin{array}{c}\text { Strict requirements } \\
\text { affect the passing } \\
\text { rate of the exam. }\end{array}$ \\
\hline JICPA & 3 & 8 & $42 \%<\mathrm{x}<52 \%$ & $\begin{array}{c}\text { Longitudinal depth, } \\
\text { strong knowledge } \\
\text { foundation. }\end{array}$ & $\begin{array}{c}\text { The comprehensive } \\
\text { coverage is relatively } \\
\text { shallow, and the } \\
\text { practical aspect is } \\
\text { relatively weak. }\end{array}$ \\
\hline
\end{tabular}




\begin{tabular}{|c|c|c|c|c|c|}
\hline WP & 2 & 8 & 6 个级次 & $\begin{array}{c}\text { levels Aimed at training, } \\
\text { focus on professional } \\
\text { practical ability. }\end{array}$ & $\begin{array}{c}\text { The subject content } \\
\text { is relatively narrow } \\
\text { and the knowledge } \\
\text { investigation is } \\
\text { limited. }\end{array}$ \\
\hline AUCPA & 3 & 14 & $450 / 900$ & $\begin{array}{c}\text { has a clear level control } \\
\text { and broad opportunities } \\
\text { for horizontal } \\
\text { development. }\end{array}$ & $\begin{array}{c}\text { The inspections are } \\
\text { too strict and } \\
\text { demanding of } \\
\text { experience. }\end{array}$ \\
\hline
\end{tabular}

Note: Because the score standard is not uniform, the author of some subjects did not list the corresponding score in the table.

As shown in Table 1, among the subjects of this study, the exam phase in the United States is the simplest and there are relatively few subjects. However, the content of the investigation is highly innovative. It is flexible to examine the various ability levels of the students and observe their passing scores. It can be seen that the requirements for candidates are general. The ACCA exam in the UK has relatively more subjects, involving financial, management and other knowledge content and levels, and the content of the investigation is relatively broad. The 13 subjects are divided into two stages and four modules to be inspected one by one. The professional content and practical experience are relatively mature in form. USCPA adopts the form of learning courses for assessment, integrating education and assessment, giving full play to the strengths of candidates, and laying the foundation for cultivating multi-directional professionals. China's inspection is also a combination of theoretical examination and practice, but innovation in professional inspection should be strengthened to speed up the pace of the accounting examination system.

In summary, it can be found that the CPA examination systems in many countries require both professional knowledge and practical experience. It can be seen that the international requirements of CPAs are not only the ability to learn and understand, but also the ability of CPAs in actual business. Flexibly use China, learn from experience, and better respond to the rapidly changing system reform and economic environment. China should also make reasonable reference to the highlights of the exam modes of various countries, continuously improve the subject content of the assessment and the form of subject inspection, better integrate with the international registered accounting examination, and cultivate more high-quality suitable for the current international accounting professional market Accounting talents. [8]

\section{RESEARCH CONCLUSIONS AND RECOMMENDATIONS}

Through a detailed comparative analysis of the examination systems of the above six countries, all countries are committed to the integration of their national registered accounting examination systems with international accounting standards, and their requirements for accounting professionals have their own emphasis on threshold setting, examination period setting and examination The selection of subjects is advancing with the times and iteratively updated. At the time of the rapid development of the global economy, the demand for international accounting services is getting bigger and bigger. Whether China can win in the fierce accounting market competition in the future depends largely on how well our accounting vocational education is done, especially how well the registered accounting examination, which is the statutory access mechanism for accounting professional qualifications, is done.

According to the above research, the multi-stage registered accounting subjects have a more in-depth investigation of the students' practical experience, not only reflecting their ability to learn and understanding, but also in-depth training of the CPA's mastery of flexible use in actual business. In terms of setting standards for the test cycle, controlling it, on the one hand, facilitates the selection of outstanding stress-resistant talents, on the other hand, it allows candidates to have a long-term buffer and summary. Germany's rapid and sophisticated shortterm system is indeed conducive to the efficient selection of top talents with strong accounting and practical abilities. However, China should focus on the long-term development of China's CPA career, and should specifically combine China's economic development level and education level. The examination period should be revised appropriately so that talents can be selected more efficiently. In terms of subject setting, China can learn from the UK's broad subject selection, improve the knowledge system of the Chinese CPA examination, increase the cross-discipline of test questions, curriculum integration, and increase the relevance and gradual nature of subjects. The examination should increase the focus of practice in the setting of question types, use more subjective questions and case questions to assess the true ability of students, establish a more scientific scoring system, and let the examination truly play a role in selecting talents.

\section{Acknowledgement}

National College Students' Entrepreneurship Practice Project, Original Creation-Cultural and Creative Supply and Demand Interactive Station Based on $(B+C) 2 B$ Business Mode 


\section{References}

1. Mao Shengliang,"Research on the Mutual Recognition System of Certified Public Accountant Qualifications in my country ,'[J]. Chinese Agricultural Accounting, 2019, No.338, 55-57. (references)

2. The analysis report of the unified national examination for certified public accountants in 2018, [J]. Chinese certified public accountants, 2019 (05): 15-23.

3. Yan Huahong, Chen Ya., "Comparative research and enlightenment of the CPA examination system," [J]. Finance and Accounting, 2019(10): 42-45.

4. Chen Maosheng, "International Comparison and Reference of CPA Examination System," [J]. Journal of Chongqing Technology and Business University. Western Forum, 2005(S1):182-183.

5. Li Wuli, "Comparison of the CPA Qualification Examination System between China and the United States," [J]. Auditing and Economic Research, 2000(01): 32-33.

6. Sai Na, "Introduction to Japan's CPA Examination System Reform," [J]. Chinese CPA, 2011 (07): 108109.

7. Yin Dequan, "The American CPA Examination System," [J]. China Examination, 2006(05): 54-55.

8. Yin Dequan, "Examination system for certified public accountants in Germany and France," [J]. China Examination, 2006(08): 58-59. 